\title{
Differences in the expression of the ASIP gene are involved in the recessive black coat colour pattern in sheep: evidence from the rare Xalda sheep breed
}

\author{
L. J. Royo*, I. Álvarez*, J. J. Arranz ${ }^{\dagger}$, I. Fernández*, A. Rodríguez*, L. Pérez-Pardal* \\ and F. Goyache* \\ *SERIDA-Somió, C/ Camino de los Claveles 604, E-33203 Gijón (Asturias), Spain. †'Departamento de Producción Animal, Universidad de \\ León, E-24071 León, Spain
}

\section{Summary}

\begin{abstract}
Here we have tested the hypothesis of association between different levels of agouti signalling peptide (ASIP) mRNA and the recessive black coat colour in the rare Xalda breed of sheep. To deal with this task, we first tested the possible action of both the dominant black extension allele $\left(E^{D}\right)$ and a 5-bp deletion (X99692:c.100_104del; $A^{\text {del }}$ ) in the ovine ASIP coding sequence on the black coat colour pattern in 188 Xalda individuals. The $E^{D}$ allele was not present in the sample and only 11 individuals were homozygous for the $A^{\text {del }} A S I P$ allele. All Xalda individuals carrying the $A^{\text {del }} / A^{\text {del }}$ genotype were phenotypically black. However, most black-coated individuals (109 out of 120) were not homozygous for the 5-bp deletion, thus rejecting the $A^{d e l} / A^{d e l}$ genotype as the sole cause of recessive black coat colour in sheep. Differences in expression of ASIP mRNA were assessed via RT-PCR in 14 black-coated and 10 white-coated Xalda individuals showing different $A S I P$ genotypes $\left(A^{w t} / A^{w t}, A^{w t} / A^{d e l}\right.$ and $\left.A^{d e l} / A^{d e l}\right)$. Levels of expression in black animals were significantly $(P<0.0001)$ lower than those assessed for white-coated individuals. However, the ASIP genotype did not influence the ASIP mRNA level of expression. The consistency of these findings with those recently reported in humans is discussed, and the need to isolate the promoter region of ovine ASIP to obtain further evidence for a role of ASIP in recessive black ovine pigmentation is pointed out.
\end{abstract}

Keywords agouti, coat colour, recessive black, RT-PCR, sheep.
The proportion of black lambs born causes substantial losses for the sheep industry (Fleet 2006). Consequently, identification of causes of recessive pigmented wool is of economic importance. Coat colour in mammals basically depends on the relative amount of the two basic types of tyrosine-derived melanin: eumelanin (black/brown) and phaeomelanin (yellow/red). The production of these pigments are controlled, in turn, by the extension $(E)$ and agouti $(A)$ loci, which are encoded by the melanocortin-1 receptor $(M C 1 R)$ and agouti signalling peptide (ASIP) loci respectively (Bultman et al. 1992). Dominant black in sheep has been shown to be caused by an extension $\left(E^{D}\right)$ allele carrying the p.M73K and p.D121N alterations in the coding sequence of the MC1R gene (Våge et al. 1999, 2003). However, the genetic basis of the

Address for correspondence

F. Goyache, SERIDA-Somió, C/ Camino de los Claveles 604, E-33203 Gijón (Asturias), Spain.

E-mail: fgoyache@serida.org

Accepted for publication 17 December 2007 recessive coat colour pattern in sheep is still poorly understood.

It is usually accepted that the white-coated phenotype has phaeomelanin background from the dominant white/tan $\left(A^{w t}\right)$ agouti allele, and that the most recessive ovine allele, non-agouti $\left(A^{a}\right)$, results in a eumelanic (black/brown) coat pattern (Sponenberg 1997). In this respect, various analyses have reported linkage between non-dominant pigmentation in sheep and DNA markers on ovine chromosome 13, where the ovine agouti locus maps, indicating that the ASIP gene would be a positional candidate for recessive pigmentation in sheep (Parsons et al. 1999a; Beraldi et al. 2006). A 5-bp deletion (X99692:c.100_104del; note that the reference sequence X99692 is the B. taurus ASIP sequence, not the ovine ASIP sequence) has been described in exon 2 of the ovine ASIP gene, but its co-segregation with the recessive pigmentation phenotype in sheep has not been unambiguously determined so far (Smit et al. 2001, 2002). We have partially sequenced ovine ASIP exon 2 and intron 2 , and the same deletion (c.100_104del) was found. This exon 2 sequence (EU274425, nt 1 to 135) showed 100\% 
homology with the ovine cDNA agouti sequence EU057181 (Parsons et al. 1999b) except for the 5-bp deletion (c.100_104del) and 100\% homology with the agouti-like sequence AY062211 (Smit et al. 2001). Even though the coding sequence of the ASIP gene is not the determinant of coat colour variation in all mammalian species (Royo et al. 2005; Drögemüller et al. 2006), the genetic scenario described by Smit et al. (2002) contrasts with that reported by Rieder et al. (2001) in horses in which a 11-bp deletion in exon 2 (AF288358:g.2174_2184del) is responsible for recessive black coat colour. Smit et al. (2002) suggested a model of segregation with two loci and two alleles per locus in which the wild-type allele $\left(A^{w t}\right)$ is segregating from the ovine agouti locus and the deletion allele $\left(A^{d e l}\right)$ is segregating from a separate, agouti-like locus in the ovine genome.

Following Våge et al. (1999, 2003), we have tested the presence of the $E^{D}$ allele in four black-coloured sheep breeds: three Spanish breeds (Xalda, Black Merino and Black Castellana) and Karakul (Table 1). The only breed with no presence of the $E^{D}$ allele was the Xalda sheep. The Xalda sheep is a rare breed in which black coat colour is traditionally segregating and, at present, is selected for by breeders (Álvarez Sevilla et al. 2003; Goyache et al. 2003). However, a substantial proportion of Xalda individuals are still white-coated, thus supporting the idea of recessive pattern(s) of inheritance of the trait. The Xalda individuals were genotyped for the presence of the $A^{\text {del }}$ allele. A PCR protocol was designed using primers flanking the deletion (5'-GCACCTGAGGAAAAGCCCAGAGATG-3' and 5'-CTTGATTCCTCCAGAATTGTTCTG-3'), and alleles were determined based on its size (242 bp for the $A$ allele, and $237 \mathrm{bp}$ for the $A^{\text {del }}$ allele) on an ALFexpressII automated sequencer (Amersham Biosciences). All Xalda individuals carrying the $A^{d e l} / A^{d e l}$ genotype were phenotypically black. However, most black-coated Xalda individuals (91\%) were not homozygous for the c.100_104del mutation, thus rejecting the $A^{d e l} / A^{d e l}$ genotype as the sole cause of recessive black coat colour in sheep.

Recently, Voisey et al. (2006) have reported that differences in dark hair colour in humans are strongly associated with different levels of ASIP mRNA. We have obtained skin samples from 24 (14 black-coated and 10 white-coated) Xalda individuals so as to assess possible differences in expression of the ovine ASIP mRNA (Fig. 1). Total RNA was extracted using a guanidine isothiocyanate-phenol technique (TRIzol ${ }^{\circledR}$ Reagent, GibcoBRL ${ }^{\circledR}$ ), treated with DNaseI $\left(\right.$ TAKARA Bio ${ }^{\circledR}$ ) and reverse-transcribed into single-stranded cDNA (First Strand cDNA Synthesis Kit for RT-PCR, AMV, Roche ${ }^{\circledR}$ ). The mRNA levels of ASIP and GAPDH were measured by quantitative PCR with the iCycler Real Time PCR detection system (BioRad ${ }^{\circledR}$ ) using the SYBR Green PCR Supermix $\left(\operatorname{BioRad}^{\circledR}\right)$. A 271-bp fragment of the ovine agouti gene was amplified using primers 5'-CACTCAGGCCTCC CAGGATGGATG-3' (forward) and 5'-CGTGCCACGTTCTTC ATCGGAG-3' (reverse). A 274-bp fragment of the ovine GAPDH gene was amplified using primers 5'-GTCACCAG GGCTGCTTTTAATTC-3' (forward) and 5'-CCAGCCTTCTC CATGGTAGTGA-3' (reverse). The GAPDH transcript was used as endogenous control following Drögemüller et al. (2006) for pig agouti skin expression. Each individual cDNA sample was amplified in duplicate and the real-time assay was repeated twice. Expression was estimated by the $\Delta \Delta \mathrm{Ct}$ method (Drögemüller et al. 2006).

Level of expression was treated as a continuous variable and statistically analysed using PROCGLM of the SAS/STAT ${ }^{\circledR}$ package, fitting a linear model that included as fixed effects the phenotype (with two levels: white and black) and the agouti genotype (with three levels: $A^{w t} / A^{w t}, A^{w t} / A^{d e l}$ and $\left.A^{d e l} / A^{d e l}\right)$. The phenotype was significantly associated with ASIP mRNA levels $(P<0.0001$; least square means of 735.17 and 13.60 for white and black individuals respectively) whilst genotype was not $(P=0.531)$. Voisey et al. (2006) reported that differences in expression of the human ASIP mRNA are associated with a polymorphism in the 3'UTR region of ASIP, with unknown functionality, which could affect mRNA stability or could be in linkage disequilibrium with a promoter polymorphism affecting transcription. A similar hypothesis can be proposed as a partial explanation of the recessive black coat colour pattern in sheep.

It is well known that various segregation patterns affecting the same or different loci can produce similar

Table 1 Absolute frequencies of the extension and agouti genotypes considering the dominant $\left(E^{D}\right)$ and wild-type $\left(E^{+}\right) M C 1 R$ alleles and the wild-type and 5-bp deletion ( $A^{\text {wt }}$ and $A^{\text {del }}$ respectively) ASIP alleles in three Spanish sheep breeds in which the black coat is segregating (Xalda) or fixed (Black Merino and Black Castellana), as well as in the Karakul breed.

\begin{tabular}{|c|c|c|c|c|c|c|c|}
\hline \multirow[b]{2}{*}{ Breed } & \multirow[b]{2}{*}{$n$} & \multicolumn{3}{|c|}{ Extension locus genotype } & \multicolumn{3}{|c|}{ Agouti locus genotype } \\
\hline & & $E^{D} / E^{D}$ & $E^{D} / E^{+}$ & $E^{+} / E^{+}$ & $A^{w t} / A^{w t}$ & $A^{w t} / A^{d e l}$ & $A^{\text {del }} / A^{\text {del }}$ \\
\hline Black-coated Xalda & 120 & 0 & 0 & 120 & 52 & 57 & 11 \\
\hline White-coated Xalda & 68 & 0 & 0 & 68 & 20 & 48 & 0 \\
\hline Karakul & 5 & 5 & 0 & 0 & 5 & 0 & 0 \\
\hline Black Merino & 12 & 12 & 0 & 0 & 1 & 11 & 0 \\
\hline Black Castellana & 30 & 30 & 0 & 0 & 12 & 17 & 1 \\
\hline
\end{tabular}

ASIP, agouti signalling peptide; MC1R, melanocortin-1 receptor. 


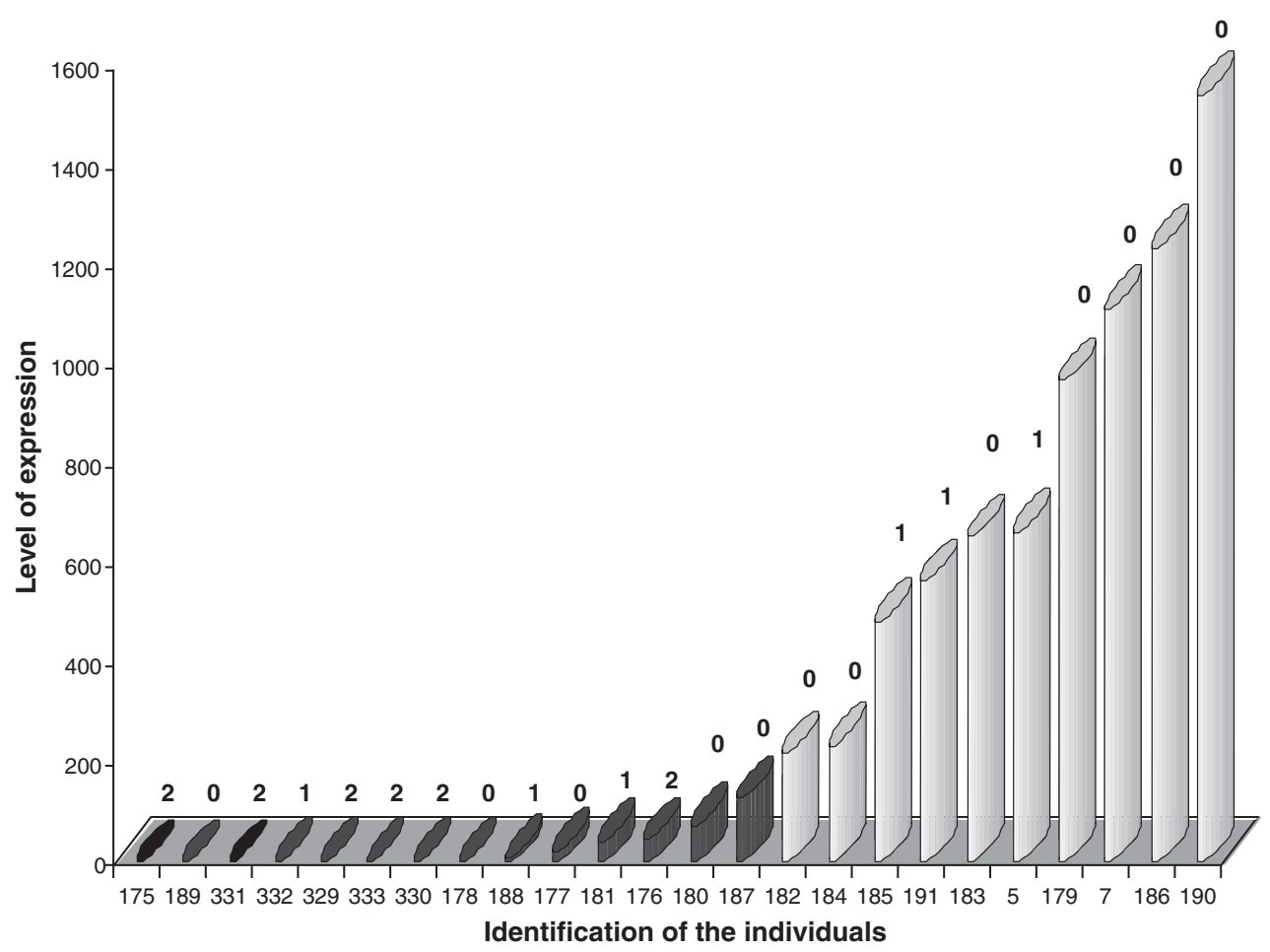

Figure 1 Differences in agouti signalling peptide (ASIP) skin mRNA expression in 24 Xalda individuals. Black-coated phenotypes are in black bars whilst white-coated phenotypes are in grey bars. Numbers on the top of the bars mean different $A S I P$ genotypes: $0\left(A^{w t} / A^{w t}\right) ; 1\left(A^{w t} / A^{d e l}\right)$; and $2\left(A^{d e l} / A^{d e l}\right)$.

phenotypes in sheep (Sponenberg 1997) and, for instance, a white-coated phenotype can be produced by the action of agouti alleles but also by the spotting locus. In contrast with previous work (Smit et al. 2001), here we have determined that the dominant black allele $\left(E^{D}\right)$ is not affecting our results and, from our data, we cannot reject that the homozygous $A^{d e l} / A^{d e l}$ genotype could cause by itself recessive black-coated phenotype in sheep. However, this genotype cannot be the sole cause of the black recessive pigmentation pattern, and differences in expression of ASIP mRNA are also associated with this phenotype regardless of agouti genotype. These results also suggest that there may only be a single agouti locus segregating in the Xalda breed. As in humans, the promoter region of ovine ASIP has yet to be isolated and may provide further evidence for a role of ASIP gene in recessive black ovine pigmentation.

\section{Acknowledgements}

This work was partially funded by a grant from MEC-INIA (No. RZ2004-00007-C02). Thanks to Asociación Española de Criadores de Ganado Ovino Selecto de Raza Castellana (ANCA) and CENSYRA-Badajoz for their help in sampling. The authors are indebted to the Xalda Breeders Association (ACOXA; http://www.xalda.com/) for its kind collaboration.

\section{References}

Álvarez Sevilla A., Gutiérrez J.P., Fernández I., Royo L.J., Álvarez I., Gómez E. \& Goyache F. (2003) Conservación de la oveja Xalda de Asturias. Animal Genetic Resources Information (FAO/UNEP) 34, 41-9.

Beraldi D., McRae A.F., Gratten J., Slate J., Visscher P.M. \& Pemberton J.M. (2006) Development of a linkage map and mapping of phenotypic polymorphisms in a free-living population of Soay sheep (Ovis aries). Genetics 173, 1521-37.

Bultman S.J., Michaud E.J. \& Woychik R.P. (1992) Molecular characterization of the mouse agouti locus. Cell 71, 1195-204.

Drögemüller C., Giese A., Martins-Wess F., Wiedemann S., Andersson L., Brenig B., Fries R. \& Leeb T. (2006) The mutation causing the black-and-tan pigmentation phenotype of Mangalitza pigs maps to the porcine ASIP locus but does not affect its coding sequence. Mammalian Genome 17, 58-66.

Fleet M.R. (2006) Development of black-pigmented skin spots and pigmented wool fibres in a Merino flock - causes, field observations and wool measurement. Australian Journal of Agricultural Research 57, 751-60.

Goyache F., Gutiérrez J.P., Fernández I., Gómez E., Álvarez I., Díez J. \& Royo L.J. (2003) Monitoring pedigree information to conserve the genetic variability in endangered populations: the Xalda sheep breed of Asturias as an example. Journal of Animal Breeding and Genetics 120, 95-103.

Parsons Y.M., Fleet M.R. \& Cooper D.W. (1999a) The Agouti gene: a positional candidate for recessive self-colour pigmentation in 
Australian Merino Sheep. Australian Journal of Agricultural Research 50, 1099-103.

Parsons Y.M., Fleet M.R. \& Cooper D.W. (1999b) Isolation of the ovine agouti coding sequence. Pigment Cell Research 12, 394-7.

Rieder S., Taourit S., Mariat D., Langlois B. \& Guérin G. (2001) Mutations in the agouti (ASIP), the extension (MC1R) and the brown (TYRP1) loci and their association to coat color phenotypes in horses (Equus caballus). Mammalian Genome 12, $450-5$.

Royo L.J., Álvarez I., Fernández I., Arranz J.J., Gómez E. \& Goyache F. (2005) The coding sequence of the ASIP gene is identical in nine wild-type coloured cattle breeds. Journal of Animal Breeding and Genetics 122, 357-60.

Smit M.A., Shay T.L. \& Cockett N.E. (2001) A mutation at the agouti locus is associated with recessive black coat color in sheep. Proceedings of the Western Section of the American Society of Animal Science, No. 52, Montana State University, Bozeman.
Smit M.A., Shay T.L., Beever J.E., Notter D.R. \& Cockett N.E. (2002) Identification of an agouti-like locus in sheep. Animal Genetics 33, $383-5$.

Sponenberg T.A. (1997) Genetics of colour and hair texture. In: The Genetics of Sheep (Ed. by L. Fries \& A. Ruvinsky), pp. 51-86. CAB International, University Press, Cambridge, UK.

Våge D.I., Klungland H., Lu D. \& Cone R.D. (1999) Molecular and pharmacological characterization of dominant black coat colour in sheep. Mammalian Genome 10, 39-43.

Våge D.I., Fleet M.R., Ponz R. et al. (2003) Mapping and characterization of the dominant black colour locus in sheep. Pigment Cell Research 16, 693-7.

Voisey J., Gomez-Cabrera M.C., Smit D.J., Leonard J.H., Sturm R.A. \& van Daal A. (2006) A polymorphism in the agouti signalling protein (ASIP) is associated with decreased levels of mRNA. Pigment Cell Research 19, 226-31. 